\title{
A developmental approach to homology and brain evolution
}

\author{
Un enfoque embriológico a la homología y la evolución cerebral
}

\author{
FRANCISCO ABOITIZ
}

Departamento de Psiquiatría y Centro de Investigaciones Médicas, Escuela de Medicina, Pontificia Universidad Católica de Chile, Marcoleta 391, Santiago, Chile e-mail: faboitiz@uc.cl

\begin{abstract}
Although homology is central to evolutionary interpretations, establishing it has become a highly disputed issue in some instances. Here I argue for a developmental understanding of evolution, where modifications of the developmental programs are a key source of evolutionary novelty. Although this perspective is not new, in comparative neurobiology it has remained controversial. Specifically, the evolutionary origin of the mammalian neocortex has been a particularly debated point. I propose a perspective that could help reconcile a long standing controversy: either the mammalian neocortex corresponds as a whole to the dorsal hemisphere of reptiles and birds, or alternatively its lateral aspect corresponds to the lateral cerebral hemisphere and is partly homologous to the dorsal ventricular ridge (DVR), a brain mass that receives the bulk of sensory input in reptiles and birds. Genetic and embryonic evidence strongly favor a dorsal origin for the whole neocortex, while the DVR derives from the lateral hemisphere. Nevertheless, the phylogenetically new elements of both the neocortex and the avian DVR derive largely from intermediate progenitor cells located in the embryonic subventricular zone (SVZ), a zone of late proliferating activity located deep to the ventral, the lateral and the dorsal hemisphere. I suggest that, despite originating in different embryonic regions (lateral vs. dorsal hemisphere), the evolutionary new cellular elements in both the avian brain and in the mammalian neocortex derive from the activation of a similar genetic pathway, possibly activated by the gene Pax-6, that induces the late proliferation of embryonic neural progenitors. This pathway can be ancestral to amniotes, reflecting genetic homology. In mammals and birds independently, this precursor proliferative activity differentiated into an SVZ, recruiting neuronal precursors from different parts of the cerebral hemisphere in each group, to contribute to brain expansion.
\end{abstract}

Key words: dorsal ventricular ridge, neocortex, pallium, subventricular zone, ventricular zone.

\section{RESUMEN}

Si bien la homología es central en las interpretaciones evolutivas, en algunos casos su determinación ha sido causa de fuertes discusiones. Aquí propongo un enfoque evolutivo basado en la embriología, donde las modificaciones de los programas de desarrollo son una fuente crucial de novedad evolutiva. Si bien esta propuesta no es nueva, ha sido controversial en la neurobiología comparada. Específicamente, el origen de la neocorteza de los mamíferos es un tópico altamente debatido. Sugiero una perspectiva que podría ayudar a reconciliar dos antiguas posiciones en conflicto: la neocorteza deriva ya sea del hemisferio dorsal de los reptiles y aves, o alternativamente parte de ella deriva del hemisferio lateral y es homóloga a una estructura llamada cresta dorsoventricular (DVR) del cerebro de los reptiles y aves, que recibe la mayor parte de las proyecciones sensoriales. La evidencia embriológica y genética apoya fuertemente un origen dorsal de toda la neocorteza, en tanto que la DVR deriva del hemisferio lateral. Sin embargo, las células filogenéticamente más nuevas de la neocorteza y de la DVR derivan en gran parte de células llamadas precursores intermedios, localizados en una profunda región embriónica llamada zona subventricular (SVZ), que mantiene la proliferación celular hasta etapas tardías del desarrollo en el hemisferio dorsal, lateral y ventral. Por lo tanto, a pesar de originarse en distintas regiones embriónicas (hemisferio lateral vs. dorsal), los nuevos elementos celulares que componen la neocorteza de mamíferos y el cerebro de las aves derivarían de la activación de una vía genética similar, posiblemente activada por el gen Pax-6, que produce la división tardía de los precursores neuronales. Dicha vía podría ser ancestral a los amniotos, reflejando homología genética. Esta actividad precursora se diferenció en una SVZ en forma independiente en mamíferos y aves, reclutando precursores neuronales de distintas regiones embriónicas en cada grupo para contribuír a la expansión cerebral.

Palabras clave: cresta dorso ventricular, neocorteza, palio, zona subventricular, zona ventricular

\section{INTRODUCTION}

Despite its pre evolutionary origin (Owen 1837), the concept of homology of organs (the "same" organ indifferent animals, despite its variety of forms) has pervaded evolutionary interpretations until today. No comparative interpretation among different species is devoid 
of the explicit or implict use of this concept, which was first proposed to denote a common design in different animals, but with Darwin's interpretation acquired a historical dimension, implying a common evolutionary origin from the most recent common ancestor. Even if understood in a completely new light, the criteria to establish homology have remained essentially the same in pre- and post-darwinian times (only technically more sophisticated): topographical position, embryonic origin, or the presence of unambiguous markers (be them morphological or chemical) (Aboitiz 1995). Notwithstanding all these technical advances, homology keeps being a sometimes highly controversial concept. There are always exceptions to each criterion, and it is not uncommon that different criteria point to different interpretations (De Beer 1971). Striedter \& Northcutt (1991) called attention to a common source of misinterpretations in this field, which is that homology can be found at different levels (there are homologous adult organs, homologous embryonic organs, homologous cell types, homologous genes and even homologous behaviors), and homology at one level does not necessarily imply homology at different levels. For example, nonhomologous embryonic structures may produce homologous adult structures. This usually occurs when early developmental mechanisms become distorted due to ecological adaptations (for example, differences in yolk production, which alter the cleavage patterns and the specification of germ layers; De Beer 1971). In this case, the adult structure remains in phylogeny (adult homology), but is produced by different developmental processes in each species. On the other hand, and perhaps more commonly, homologous embryonic structures may yield non homologous adult structures in two species if the developmental programs have diverged in evolution after the specification of an embryonic primordium. In these cases, some speak of "field homology" or simply "embryonic homology" (Northcutt 1999, Butler \& Molnár 2002, Aboitiz \& Montiel 2007). As a way to come out of these complications and ambiguities, I propose the (difficult) task of reconstructing the ontogenetic transformations that took place during a phylogenetic divergence of two related taxa. This position takes line with Walter Garstang's dictum "ontogeny does not recapitulate phylogeny: it creates it.” (Garstang 1922, p. 724).

Although dismissed during the early half of last century, the developmental approach to evolution regained solid ground with Stephen Jay Gould's "Ontogeny and Phylogeny" (Gould 1977), and grew into the now fashionable "evodevo" trend (Gerhart \& Kirschner 1997, Kirschner \& Gerhart 2005), whose study object is the evolution of developmental patterns. This strategy has proven extremely successful in some areas of morphology, particularly in the study of body axis specification and vertebrate limb evolution (Vargas et al. 2008, Shubin et al. 2009). Nevertheless, in other areas such as the evolution of the vertebrate brain, the application of this approach remains controversial. In the following of this article, I will briefly review the history and actual stance of what has perhaps been "the thorniest problem of comparative neurobiology" (Northcutt 2003, p. 565), which is the origin of the mammalian neocortex from a reptilian-like brain. For obvious reasons, the evolution of our brain, the seat of language and consciousness, has a special status among bodily parts if we are to remain self-centered, and consequently there have been agitated controversies on this subject since the beginnings of comparative neuroanatomy. I expect that this discussion will serve as a good example of how developmental and genetic information can provide insight into the evolution of an extremely important organ, and how it may help to solve ancient and seemingly irreconciliate controversies.

\section{Case study: The origin of the mammalian neocortex}

In order to provide some phylogenetic context, let me briefly state that amniotes (terrestrial vertebrates who lay their eggs on ground or gestate them in the womb) are subdivided into sauropsids (reptiles and birds) and mammals. While it is usually acknowledged that amniotes make up a monophyletic group, living synapsids and sauropsids are "maximally distant" in the sense that their common ancestor goes back to the earliest amniotes on the planet. In line with this early divergence, the brains of mammals and sauropsids are 
morphologically very different, yet organized according to a common embryonic plan (see Fig. 1A). While mammals show the noticeable expansion of the neocortex in the brain's surface, in sauropsids (especially reptiles) the cortical tissue is surprisingly small, and there is a conspicuous internal neural mass that grows into the lateral cerebral ventricle (the dorsal ventricular ridge, DVR) (see Fig. 1B).

In a now classic work, Harvey Kartén observed that the lateral neocortex of mammals (i.e. the auditory cortex and the secondary/tertiary visual cortices) received the same kind of sensory projections as the reptilian/avian DVR. On the other hand, the mammalian primary visual cortex was likened to the reptilian dorsal cortex and its avian equivalent (the hyperpallium) since both receive visual projections from the thalamic lateral geniculate nucleus (see Fig. 1B). Therefore, he concluded, the dorsal cortex of reptiles (hyperpallium of birds) is homologous to the mammalian primary visual cortex, and part of the DVR is homologous to the mammalian lateral neocortex (Kartén 1968, 1969). In other words, the mammalian neocortex would have two separate origins: one part deriving from the dorsal cortex (dorsal pallium; see Fig. 1A), and the other from the DVR.

Despite these connectional similarities, some authors disagreed with this interpretation, on the basis of (i) a different topographical position and embryonic origin of the neocortex and the DVR (Aboitiz 1992, 1995, Striedter 1997, 2005), and (ii) different patterns of overall connectivity of these structures with the rest of the brain (Bruce \& Neary 1995). Genetic developmental analyses of the vertebrate hemispheres (SmithFernández et al. 1998, Striedter et al. 1998, Puelles et al. 1999, 2000, Abellán et al. 2009) elegantly demonstrated that both, the whole mammalian neocortex (lateral and dorsal) and the reptilian dorsal cortex derive from a dorsal embryonic territory (the dorsal pallium, see Fig. 1A), while the DVR derives largely from the lateral aspect of the cerebral hemisphere (the ventral pallium, Fig. 1A). This evidence indicated a common embryonic origin of the sauropsidian DVR and part of the mammalian claustroamygdaloid complex, a deep brain structure involved in emotional responses
(Fig. 1). Interestingly, this interpretation had been previously made by some early comparative neuroanatomists (Holmgren 1922). Additional studies in mammals evidenced a strong auditory and visual projection from posterior thalamic nuclei to amygdalar components, further supporting a relationship between this structure and at least part of the claustroamygdalar system (Doron \& LeDoux 1999, 2000).

Moreover, what makes the neocortex unique is its conspicuous laminar organization into six layers, a characteristic not found in any other vertebrate brain. These layers develop through the migration of excitatory cells, traveling in a predominantly radial direction from the ventricular surface to the surface of the hemispheres where they originate (Fig. 2A). Inhibitory neurons originate in the ventral hemisphere (the subpallium), and migrate following an oblique or tangential direction towards the dorsal pallial territory; this is an ancient character possibly present in amphibians and has no direct relation to the origin of the neocortex (Anderson et al. 1997, see Aboitiz \& Montiel 2007). Furthermore, the cortical neurogenetic sequence is counter-intuitive and highly special: deeper layers are generated first, and more superficial layers are each produced at later developmental times, with the result that late-produced neurons that migrate radially have to pass the layers already formed by early-produced neurons (Rakic 1974). Importantly, developmental and neurochemical analyses converged in showing that the developmentally early-produced layers showed similarity with the reptilian cortical cells, while the late-produced layers represent phylogenetically new neuronal phenotypes, possibly acquired during neocortical origins (see Aboitiz et al. 2003).

Neocortical neurons derive from two kinds of precursor cells: the primary progenitors are the embryonic radial glia, which divide and produce two daughter cells: (i) another radial glia and (ii) a second cell that, either differentiates directly as a neuron, or becomes an intermediate progenitor that keeps dividing for two or three rounds and its progeny eventually differentiates into neurons. Interestingly, the early- and the late-produced neurons in the cerebral cortex (deep and 
(A)

\section{EMBRYO}

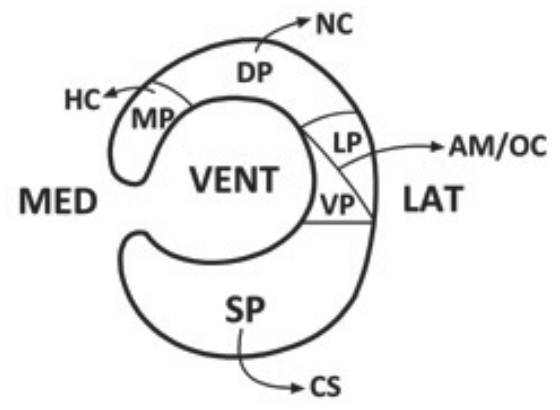

(B)

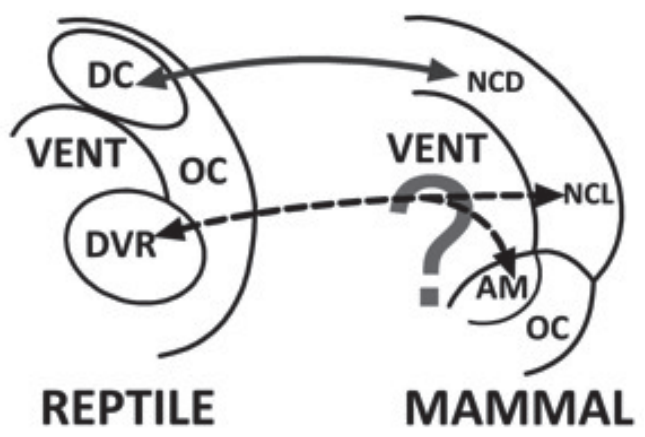

Fig. 1: (A) Scheme depicting the basic topographic organization of the mammalian embryonic cerebral hemisphere. The subpallium (SP) represents the ventral hemisphere, which will derive in the corpus striatum (CS) and other structures. The pallium corresponds to the "roof" of the cerebral hemisphere, and is the structure discussed in this article. The pallium is subdivided into several components. In the lateral hemisphere, the lateral and ventral pallium (LP and VP) give rise to the olfactory cortex (OC) and part of the claustroamygdaloid complex (AM). In the dorsal hemisphere, the dorsal pallium (DP) becomes the mammalian neocortex (NC) (corresponding to the reptilian dorsal cortex -DC- or hyperpallium of birds). Finally, the medial hemisphere (more precisely, dorsomedial) corresponds to the medial pallium (MP), which generates the hippocampal cortex (HC). This general embryonic plan holds for other vertebrate brains. (B) Comparison between reptilian and mammalian brains. The dorsal cortex (DC) of reptiles (left) derives from the embryonic dorsal pallium, like the mammalian neocortex (see Fig. 1A), and has similar connections to the dorsal neocortex (NCD, primary visual and somatosensory cortices). On the other hand, the reptilian dorsal ventricular ridge (DVR), deriving from the lateral hemisphere (more specifically, the ventral pallium, VP in Fig. 1A) has been likened either to the mammalian lateral neocortex (NCL, including the auditory cortex and the secondary and tertiary visual cortices) or to the claustroamygdaloid complex (AM) of the lateral hemisphere. This is the controversy discussed in this article. For further details, see Aboitiz \& Montiel (2007). LAT, lateral; MED, medial; VENT, cerebral ventricle.

(A) Esquema indicando la organización básica del hemisferio cerebral de mamíferos en su forma embriónica. El subpalio (SP) representa el hemisferio ventral, el cual derivará en el cuerpo estriado (CS) y otras estructuras. El palio corresponde al "techo" del hemisferio cerebral, y es la estructura que se discute en este artículo. El palio se subdivide en varios componentes. En el hemisferio lateral, el palio lateral y ventral (LP y VP) dan lugar a la corteza olfatoria (OC) y a parte del complejo claustroamigdalino (AM). En el hemisferio dorsal, el palio dorsal deviene en la neocorteza de mamíferos (NC) (correspondiente a la corteza dorsal -DC- de reptiles o hiperpalio de aves). Finalmente, el hemisferio medial (más precisamente, dorsomedial) corresponde al palio medial (MP), que genera la corteza hipocampal (HC). Este plan embriónico general se mantiene para otros cerebros de vertebrados. (B) Comparación entre los cerebros de reptil y de mamífero. La corteza dorsal (DC) de reptiles (izquierda) deriva del palio dorsal embrionario, al igual que la neocorteza de mamíferos (ver Fig. 1A), y posee conexiones similares a la neocorteza dorsal (NCD, cortezas visual y somatosensorial primarias). Por otro lado, la cresta dorsoventricular de reptiles (DVR), que deriva del hemisferio lateral (más específicamente, del palio ventral, VP en la Fig. 1A) ha sido comparada ya sea con la neocorteza lateral (NCL, incluyendo a la corteza auditiva y las cortezas visuales secundaria y terciarias) o al complejo claustroamigdalino (AM) del hemisferio lateral. Esta es la controversia que se discute en este artículo. Para mayores detalles, ver Aboitiz \& Montiel (2007). LAT, lateral; MED, medial; VENT, ventrículo cerebral. 
(A)
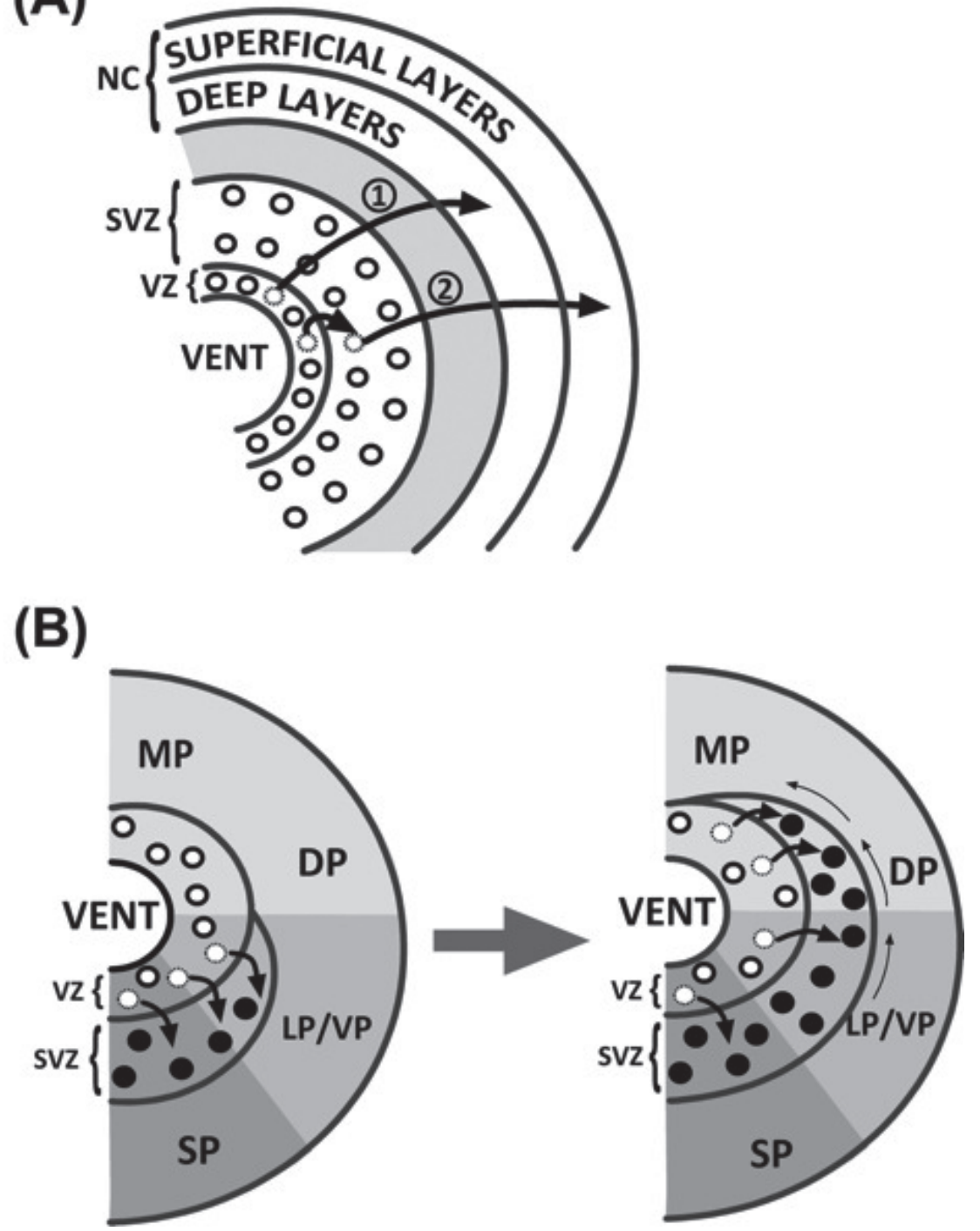

Fig. 2: (A) In the developing neocortex, cell proliferation takes place in the layers surrounding the ventricular wall (the ventricular zone, $\mathrm{VZ}$ and the subventricular zone, SVZ). Neural progenitors in the VZ give rise to intermediate progenitors in the SVZ, which keep dividing and producing neurons until late developmental stages (short arrow). Both progenitors in the VZ and intermediate progenitors in the SVZ produce differentiating excitatory neurons that migrate in a roughly radial direction to the external wall, producing the neocortex $(\mathrm{NC})$. Early produced neurons tend to be generated in the VZ, and make up the deepest cortical layers (see arrow 1), while late- produced neurons are generated in the SVZ, migrate past the deep layers and make up the more superficial layers (see arrow 2). (B) Expansion of the late-proliferating activity in the SVZ from the lateral hemisphere (LP/VP) into dorsal pallial territory (DP, which gives rise to the neocortex). This process occurs in ontogeny and is also claimed to have been crucial for the evolutionary origin of the neocortex.

(A) En la neocorteza embriónica, la proliferación celular tiene lugar en las capas que rodean la pared ventricular (la zona ventricular, VZ y la zona subventricular, SVZ). Los progenitores en la VZ dan lugar a progenitores intermedios en la SVZ, que continúan dividiéndose y produciendo neuronas hasta estadíos embriónicos tardíos (flecha corta). Ambos, los progenitores en la VZ y los progenitores intermedios en la SVZ, producen neuronas excitatorias que migran radialmente hacia la pared externa, produciendo la neocorteza $(\mathrm{NC})$. Las neuronas producidas tempranamente tienden a ser generadas en la VZ, y conforman las capas corticales más profundas (ver flecha 1), en tanto que las neuronas producidas tardíamente se generan en la SVZ, migran a través de las capas profundas y forman las capas superficiales (ver flecha 2). (B) Expansión de la actividad proliferativa tardía en la SVZ desde el hemisferio lateral (LP/VP) hacia el palio dorsal (DP, que da lugar a la neocorteza). Este proceso ocurre en la ontogenia y se propone que fue crucial para el origen evolutivo de la neocorteza. 
superficial layers, respectively) belong to different developmental "compartments": early neurons originate predominantly from primary and intermediate progenitor cells located in the so-called ventricular zone (VZ), a proliferative layer lining the ventricular wall of the hemisphere. On the other hand, lateproduced neurons originate mostly form a second, later-formed proliferative layer above the ventricular zone, termed the subventricular zone (SVZ), which houses intermediate progenitors that originate in the $\mathrm{VZ}$ and migrate there (Kowalczyk et al. 2009, see Fig. 2A). The mammalian SVZ is highly prominent in the ventral and lateral aspects of the embryonic cerebral hemisphere, but in later stages expands into the dorsal hemisphere, contributing to generate neurons for the neocortex (Fig. 2B). The proliferative activity of the SVZ tends to cease around birth in the dorsal hemisphere, but remains in the ventrolateral hemisphere, contributing to adult neurogenesis (Álvarez-Buylla et al. 2000). Interestingly, in mutant mice lacking the gene Pax-6, the cells deriving from the SVZ fail to differentiate and to migrate both radially and tangentially, resulting in a very reduced and thin neocortex, perhaps resembling the reptilian dorsal cortex (Fukuda et al. 2000, Tuoc et al. 2009). Furthermore, in this mutant the derivatives of the lateral hemisphere (i.e. the claustroamygdaloid complex, comparable to the DVR) are also highly dysgenic. Considering this evidence, we originally suggested that the origin of the mammalian neocortex was tightly associated with the development of a late-proliferating SVZ in the dorsal cerebral hemisphere (the dorsal pallium), but more specifically with the recruitment of a Pax-6- associated pathway that contributed to the generation and migration of such late-produced cells into the neocortex (Aboitiz et al. 2003).

More recent comparative studies identified an SVZ in the ventral/lateral hemisphere (subpallium/ventral pallium) of mammals and birds, while only mammals display an SVZ in the dorsal hemisphere (i.e. the neocortex; this is true for at least placental and marsupials; studies are still needed in monotremes) (Cheung et al. 2007, 2010). In crocodiles (closely related to dinosaurs and birds), the $\mathrm{SVZ}$ is restricted to the ventral hemisphere
(Abdel-Mannan et al. 2008, Charvet et al. 2009). An SVZ proper was found to be lacking in the brains of amphibians or other reptiles (turtles and lizards). These studies concluded that the SVZ differentiated independently in the mammalian and the archosaurian (crocodiles and birds) brains, and that it follows a ventral to dorsal expansion during both development and evolution (see Fig. 2B). In partial agreement with these findings, we proposed that a zone of late proliferating activity would have been present in the ventrolateral hemisphere of the early amniotes, developing into an SVZ independently in mammals and birds, and propagating into the dorsal hemisphere only in the case of mammals (Aboitiz \& Montiel 2007, p. 62). This activity may have depended on Pax6 , which at least in mammals is required for the normal development of both the lateral and the dorsal hemisphere (claustroamygdaloid complex and neocortex; see above).

Although no SVZ proper has been detected in the brains of turtles and lizards (see Charvet et al. 2009), early observations of the DVR in lizards, snakes and turtles describe it as arising from a late proliferative zone in the lateral hemisphere, emerging after the migration of cells belonging to the lateral cortex has completed (Källén 1951, see Aboitiz $\&$ Montiel 2007). Although this late activity is based mainly on the proliferation of primary progenitors (radial glia), the eventual elaboration of an SVZ bearing intermediate progenitors in birds, crocodiles and mammals has been claimed to be the mechanical consequence of rapidly increasing proliferation in the highly constrained space that is the VZ (Striedter \& Charvet 2009). Thus, it is conceivable that the appearance of an SVZ is not the main evolutionary event in neocortical or avian brain expansion, but rather a consequence of a rapid amplification of the proliferative activity in the VZ, which would be the primary process underlying telencephalic growth in both sauropsids and mammals.

Phenotypic similarity between the lateproduced components in sauropsids and mammals would be consistent with the possibility that they develop according to a similar developmental program. In fact, recent reports indicate expression of common markers between the late-produced neurons in the neocortex of mammals and those in the 
reptilian DVR (DCX-PSA + neurons; Luzzati et al. 2009), and in the avian DVR (Brn2+ neurons; Nomura et al. 2008). This suggests that a genetic program involved in the late proliferation and differentiation of neural precursors is shared by progenitors of lateproduced neurons in reptiles, birds and mammals (be them in the $\mathrm{VZ}$ as in reptiles, or in the SVZ, as in birds and mammals), and already existed in the $\mathrm{VZ}$ of early amniotes (Luzzati et al. 2009, see also Aboitiz \& Montiel 2007). Finally, phenotypic similarity between cells in the DVR and the neocortex would also explain why they ended up receiving similar sensory inputs.

\section{DISCUSSION}

I have advocated for a genetic/developmental interpretation of morphological evolution, emphasizing the modification of embryonic processes as a key element in generating evolutionary novelties. Furthermore, I focused on one specific organ, the mammalian neocortex, and described the different interpretations about its origins since the early last century comparative neuroanatomists. Genetic developmental analyses confirmed the early anatomical descriptions of the reptilian DVR arising from the lateral cerebral hemisphere (see Aboitiz \& Montiel 2007), therefore being embryologically different from the more dorsal neocortex and the more ventral corpus striatum. Nevertheless, interesting similarities exist both in the connectivity and the phenotype of the newly generated cellular components in the reptilian/avian DVR and in the mammalian neocortex, both arising from late proliferating activities in the deep hemisphere. This amplified proliferation may have taken place first in the VZ (reptiles) and eventually differentiated into an SVZ above the former in crocodiles, birds and mammals (Striedter \& Charvet 2009, Charvet et al. 2009). Another, not alternative possibility is that it consisted of scattered dividing cells located above the VZ, which eventually clustered into the SVZ (Abdel-Mannan et al. 2008). Thus, an argument can be made for evolutionary continuity of this late proliferating activity, which might be characterized by the activation of a genetic program that keeps neural precursors into the cell cycle, thus ensuring proliferation in later stages (Aboitiz \& Montiel 2007, Luzzati et al. 2009). Furthermore, I claim that this activity originates in the ventrolateral aspect of the hemisphere in the stem amniote, and in birds and mammals independently expands into the lateral and dorsal hemisphere respectively, to eventually differentiate into an SVZ. Why in mammals proliferation became concentrated in the dorsal hemisphere is still an open question, but may relate to the development of olfaction in early mammals, and to the associative networks between the lateral (olfactory) and the medial (hippocampal) cortices that elaborated in the early mammalian brain (Aboitiz \& Montiel 2007). In this context, we have proposed that the mammalian brain is characterized by an increasing "dorsalizing" morphogenetic influence emanating from the telencephalic roof plate in mammalian embryos, and from morphogenetic factors deriving from the anterior telencephalic vesicle, that in mammals pattern the mammalian cerebral cortex and restrict the development of the ventrolateral hemisphere. These factors are supposed to remain downregulated in the sauropsidian brain, thus limiting the development of the dorsal hemisphere and facilitating the expansion of the lateral hemisphere (Aboitiz et al. 2003, Aboitiz 2008). Further studies will be needed to ascertain whether this is or is not a plausible alternative.

\section{ACKNOWLEDGEMENTS}

Francisco Zamorano prepared the figures presented in this article. I am also very grateful for the insights provided by the reviewers of this article.

\section{LITERATURE CITED}

ABDEL-MANNAN O, AF CHEUNG \& Z MOLNÁR (2008) Evolution of cortical neurogenesis. Brain Research Bulletin 75: 398-404.

ABELLÁN A, I LEGAZ, B VERNIER, S RÉTAUX \& L MEDINA (2009) Olfactory and amygdalar structures of the chicken ventral pallium based on the combinatorial expression patterns of LIM and other developmental regulatory genes. Journal of Comparative Neurology 516: 166-186.

ABOITIZ F (1992) The evolutionary origin of the mammalian cerebral cortex. Biological Research 25: 41-49. 
ABOITIZ F (1995) Homology in the evolution of the cerebral hemispheres. The case of dorsal ventricular ridge and its possible correspondence with mammalian neocortex. Journal für Hirnforschung 36: 461-472.

ABOITIZ F (2008) Neocortex, origins. In: Squire L (ed) Encyclopedia of neuroscience. Fourth edition 6: 43-50. Academic Press, Oxford.

ABOITIZ F, D MORALES \& J MONTIEL (2003) The evolutionary origin of the mammalian isocortex: Towards an integrated developmental and functional approach. Behavioral and Brain Sciences 26: 535-586.

ABOITIZ F \& J MONTIEL (2007) Origin and evolution of the vertebrate telencephalon, with special reference to the mammalian neocortex. Advances in Anatomy, Embryology and Cell Biology 193: 1-111.

ÁLVAREZ-BUYLLA A, DG HERRERA \& $\mathrm{H}$ WICHTERLE (2000) The subventricular zone: Source of neuronal precursors for brain repair. Progress in Brain Research 127: 1-11.

ANDERSON SA, DD EISENSTAT, L SHI \& JLR RUBENSTEIN (1997b) Interneuron migration from basal forebrain to neocortex: Dependence on Dlx genes. Science 278: 474-476.

BUTLER AB \& Z MOLNÁR (2002) Development and evolution of the collopallium in amniotes: A new hypothesis of field homology. Brain Research Bulletin 57: 475-479.

CHARVET CJ, T OWERKOWICZ \& GF STRIEDTER (2009) Phylogeny of the telencephalic subventricular zone in sauropsids: Evidence for the sequential evolution of pallial and subpallial subventricular zones. Brain Behavior and Evolution 73: 285-294.

CHEUNG AF, AA POLLEN, A TAVARE, J DEPROTO \& Z MOLNÁR (2007) Comparative aspects of cortical neurogenesis in vertebrates. Journal of Anatomy 211: 164-176.

CHEUNG AF, S KONDO, O ABDEL-MANNAN, RA CHODROFF, TM SIREY et al. (2010) The subventricular zone is the developmental milestone of a 6-layered neocortex: Comparisons in metatherian and eutherian mammals. Cerebral Cortex 20: 1071-1081.

DE BEER GR (1971) Homology, an unsolved problem. Oxford University Press, Oxford, UK.

DESMOND A (1982) Archetypes and ancestors. Paleontology in Victorian London. University of Chicago Press, Chicago.

DORON NN \& JE LEDOUX (1999) Organization of projections to the lateral amygdala from auditory and visual areas of the thalamus in the rat. Journal of Comparative Neurology 412: 383-409.

DORON NN \& JE LEDOUX (2000) Cells in the posterior thalamus project to both amygdala and temporal cortex: A quantitative retrograde double-labeling study in the rat. Journal of Comparative Neurology 425: 257-274.

FUKUDA T, H KAWANO, N OSUMI, K ETO \& K KAWAMURA (2000) Histogenesis of the cerebral cortex in rat fetuses with a mutation in the Pax-6 gene. Developmental Brain Research 120: $65-75$

GARSTANG W (1922) The theory of recapitulation: A critical restatement of biogenetic law. Journal of the Linnean Society for Zoology 35: 81-101.

GEHRING WJ (1996) The master control gene for morphogenesis and evolution of the eye. Genes and Cells 1: 11-15.

GERHART JC \& MW KIRSCHNER (1997) Cells, embryos and evolution. Toward a cellular and developmental understanding of phenotypic variation and evolutionary adaptability. Blackwell Press, Boston, Massachusetts.

GOULD SJ (1977) Ontogeny and phylogeny. Harvard University Press, Cambridge, USA.

HOLMGREN N (1922) Points of view concerning forebrain morphology in lower vertebrates. Journal of Comparative Neurology 34: 391-459.

KÄLLEN B (1951) On the ontogeny of the reptilian forebrain. Nuclear structures and ventricular sulci. Journal of Comparative Neurology 95: 307347.

KARTÉN HJ (1968) The ascending auditory pathway in the pigeon (Columba livia). II. Telencephalic projections of the nucleus ovoidalis thalami. Brain Research 11: 134-153.

KARTÉN HJ (1969) The organization of the avian telencephalon and some speculations on the phylogeny of the amniote telencephalon. Annals of the New York Academy of Science 167: 164179.

KIELAN-JAWOROWSKA Z, RL CIFELLI \& Z LUO (2004) Mammals from the age of dinosaurs. Columbia University Press, New York.

KIRSCHNER MW \& JC GERHART (2005) The plausibility of life. Resolving Darwin's dilemma. New Haven, Yale University Press, Yale, Connecticut.

KOWALCZYK T, A PONTIOUS, C ENGLUND, RA DAZA, F BEDOGNI et al. (2009) Intermediate neuronal progenitors (basal progenitors) produce pyramidal-projection neurons for all layers of cerebral cortex. Cerebral Cortex 19: 2439-2450.

LUZZATI F, L BONFANTI, A FASOLO \& P PERETTO (2009) DCX and PSA-NCAM expression identifies a population of neurons preferentially distributed in associative areas of different pallial derivatives and vertebrate species. Cerebral Cortex 19: 1028-1041.

NOMURA T, M TAKAHASHI, Y HARA \& N OSUMI (2008) Patterns of neurogenesis and amplitude of Reelin expression are essential for making a mammalian-type cortex. Public Library of Science ONE 3: e1454.

NORTHCUTT RG (1999) Field homology: A meaningless concept. European Journal of Morphology 37: 95-99.

NORTHCUTT RG (2003) The use and abuse of developmental data. Behavioral Brain Sciences 26: $565-566$

OWEN R (1837) The hunterian lectures in comparative anatomy. Reprinted 1992, University of Chicago, Chicago, Illinois.

PARENT A \& A OLIVIER (1970) Comparative histochemical study of the corpus striatum. Journal für Hirnforschung 12: 73-81.

PUELLES L, E KUWANA, E PUELLES \& JLR RUBENSTEIN (1999) Comparison of the mammalian and avian telencephalon from the perspective of gene expression data. European Journal of Morphology 37: 139-150.

PUELLES L, E KUWANA, E PUELLES, A BULFONE, K SHIMAMURA, J KELEHER, S SMIGA \& JLR RUBENSTEIN (2000) Pallial and subpallial derivatives in the embryonic chick and mouse 
telencephalon, traced by the expression of the genes Dlx-2, Emx-1, Nkx-2.1, Pax-6 and Tbr-1. Journal of Comparative Neurology 424: 409-438.

QUIRING R, U WALLDORF, U KLOTER \& WJ GEHRING (1994) Homology of the eyeless gene of Drosophila to the small eye gene in mice and aniridia in humans. Science 265: 785-789.

RAKIC P (1974) Neurons in rhesus monkey: Systematic relation between time of origin and eventual disposition. Science 183: 425-427.

REINER AA (2000) Hypothesis as to the organization of cerebral cortex in the common amniote ancestor of modern reptiles and mammals. Novartis Foundation Symposia 228: 83-108.

SHUBIN N, C TABIN \& S CARROLL (2009) Deep homology and the origins of evolutionary novelty. Nature. 457: 818-823.

SMITH-FERNÁNDEZ A, C PIEAU, J REPÉRANT, E BONCINELLI \& M WASSEF (1998) Expression of the Emx-1 and Dlx-1 homeobox genes define three molecularly distinct domains in the telencephalon of mouse, chick, turtle and frog embryos: Implications for the evolution of telencephalic subdivisions in amniotes. Development 125: 2099-2111.

STRIEDTER GF (1997) The telencephalon of tetrapods in evolution. Brain, Behavior and Evolution 49: 179-213.

STRIEDTER GF (2005) Principles of brain evolution. Sinauer Associates, Sunderland, Massachusetts.

STRIEDTER GF \& RG NORTHCUTT (1991) Biological hierarchies and the concept of homology. Brain, Behavior and Evolution 38: 177-189.

STRIEDTER GF \& CJ CHARVET (2009) Telencephalon enlargement by the convergent evolution of expanded subventricular zones. Biological Letters 5: 134-137.

STRIEDTER GF, A MARCHANT \& S BEYDLER (1998) The "neostriatum" develops as part of the lateral pallium in birds. Journal of Neuroscience 18: 5839-5849.

TUOC TC, K RADYUSHKIN, AB TONCHEV, MC PIÑON, R ASHERY-PADAN, Z MOLNÁR, MS DAVIDOFF \& A STOYKOVA (2009) Selective cortical layering abnormalities and behavioral deficits in cortex-specific Pax6 knock-out mice. Journal of Neuroscience 29: 8335-8349.

VARGAS AO, T KOHLSDORF, JF FALLON, J VANDENBROOKS \& GP WAGNER (2008) The evolution of HoxD-11 expression in the bird wing: Insights from Alligator mississippiensis. Public Library of Science ONE 3: e3325. 
